NOTE

\title{
Sodium hypochlorite denatures the DNA of the amphibian chytrid fungus Batrachochytrium dendrobatidis
}

\author{
Scott D. Cashins ${ }^{1,2, *}$, Lee F. Skerratt ${ }^{2}$, Ross A. Alford $^{1}$ \\ ${ }^{1}$ School of Marine and Tropical Biology and Amphibian Disease Ecology Group, James Cook University, \\ Townsville, Queensland 4811, Australia \\ ${ }^{2}$ School of Public Health, Tropical Medicine and Rehabilitation Sciences and Amphibian Disease Ecology Group, \\ James Cook University, Townsville, Queensland 4811, Australia
}

\begin{abstract}
Batrachochytrium dendrobatidis, an aquatic amphibian fungus, has been implicated in many amphibian declines and extinctions. A real-time polymerase chain reaction (PCR) TaqMan ${ }^{\circledR}$ assay is now used to detect and quantify $B$. dendrobatidis on amphibians and other substrates via tissue samples, swabbing and filtration. The extreme sensitivity of this diagnostic test makes it necessary to rigorously avoid cross-contamination of samples, which can produce false positives. One technique used to eliminate contamination is to destroy the contaminating DNA by chemical means. We tested 3 concentrations of sodium hypochlorite $(\mathrm{NaOCl})(1,6$ and12\%) over 4 time periods $(1,6,15$ and $24 \mathrm{~h}$ ) to determine if $\mathrm{NaOCl}$ denatures $B$. dendrobatidis DNA sufficiently to prevent its recognition and amplification in PCR tests for the fungus. Soaking in $12 \% \mathrm{NaOCl}$ denatured $100 \%$ of DNA within $1 \mathrm{~h}$. Six percent $\mathrm{NaOCl}$ was on average $99.999 \%$ effective across all exposure periods, with only very low numbers of zoospores detected following treatment. One percent $\mathrm{NaOCl}$ was ineffective across all treatment periods. Under ideal, clean conditions treatment with $6 \% \mathrm{NaOCl}$ may be sufficient to destroy DNA and prevent cross-contamination of samples; however, we recommend treatment with $12 \% \mathrm{NaOCl}$ for $1 \mathrm{~h}$ to be confident all $B$. dendrobatidis DNA is destroyed.
\end{abstract}

KEY WORDS: Chytridiomycosis $\cdot$ Denaturation $\cdot$ Field hygiene $\cdot$ PCR $\cdot$ Diagnostic test

\section{INTRODUCTION}

Chytridiomycosis, caused by the highly virulent fungus Batrachochytrium dendrobatidis, has caused declines of natural amphibian populations and deaths in captive populations around the world (Berger et al. 1998, Pessier et al. 1999, Lips et al. 2006, Rachowicz et al. 2006, Skerratt et al. 2007). B. dendrobatidis is a highly transmissible pathogen requiring proper hygiene protocols, including disinfection of equipment, to prevent its spread (Speare et al. 2004). Many disinfectants are very effective at killing $B$. dendrobatidis on a range of substrates (Johnson et al. 2003, Webb et al. 2007). However, for researchers collecting and processing samples for diagnostic PCR, killing $B$. dendrobatidis is not enough; it is necessary to destroy its DNA to prevent cross-contamination of samples that may lead to false positives.

DNA-based PCR tests are now commonly used diagnostic tools to detect Batrachochytrium dendrobatidis due to their sensitivity and specificity (Annis et al. 2004, Boyle et al. 2004, Hyatt et al. 2007). When using diagnostic PCR, it is important to prevent contamination of samples. Even very low levels of DNA contamination on sampling equipment can create false positives. Recent papers have raised concerns regarding the generation of false positives via shared equipment (Kirshtein et al. 2007, Woodhams et al. 2007). While it is now standard practice to disinfect field equipment with bleach, $>70 \%$ ethanol or other treatments to 
prevent the transfer of live $B$. dendrobatidis among individual amphibians and sites (Johnson et al. 2003, Speare et al. 2004, Webb et al. 2007), these protocols may not denature $B$. dendrobatidis DNA. This would make the results of diagnostic PCR unreliable. Dipping instruments in alcohol and burning off the residue is an effective sterilisation technique and may render $B$. dendrobatidis DNA undetectable by PCR. However, this has not yet been tested and flaming is an impractical solution for larger field tools such as collection trays and animal enclosures and equipment that would be destroyed by flames such as fabrics and plastics.

The antimicrobial properties of sodium hypochlorite $(\mathrm{NaOCl})$ are well known and it is widely used as a disinfectant in medicine (Eventov et al. 1998), endodontics (Gomes et al. 2001), water treatment and around the home. Archaeologists and forensic scientists have discovered its usefulness for destroying contaminating DNA prior to PCR amplification of target DNA from teeth and bones (Kemp \& Smith 2005). NaOCl has also been used to denature pathogens and allergens. Sehulster et al. (1981) found that $\mathrm{NaOCl}$ eliminates Hepatitis B antigenicity; Matsui et al. (2003) reduced the immunogenicity of a cat allergen, and Martyny et al. (2005) denatured the fungal allergen Aspergillus fumigatus on environmental substrates, significantly reducing its recognition by ELISA. We experimentally tested 3 concentrations of $\mathrm{NaOCl}$ over 4 exposure periods to determine its effectiveness at denaturing Batrachochytrium dendrobatidis DNA as determined through a real-time PCR assay.

\section{MATERIALS AND METHODS}

We maintained Batrachochytrium dendrobatidis culture in TGHL broth (16 g tryptone, $4 \mathrm{~g}$ gelatine hydrolysate, $2 \mathrm{~g}$ lactose, $10 \mathrm{~g}$ agar, and $1000 \mathrm{ml}$ distilled $\mathrm{H}_{2} \mathrm{O}$ ) in $75 \mathrm{~cm}^{2}$ tissue culture flasks (Sarstedt) at $20^{\circ} \mathrm{C}$. After $4 \mathrm{~d}$, the flask bottom was scraped with a cell scraper to dislodge all encysted zoospores and zoosporangia. The entire cell suspension ( $30 \mathrm{ml})$ was emptied into a $50 \mathrm{ml}$ centrifuge tube and centrifuged at $1100 \mathrm{~g}$ for $5 \mathrm{~min}$ at $4^{\circ} \mathrm{C}$. The supernatant, containing the reproductive zoospores, was then transferred to a clean tube and the pellet, consisting mostly of zoosporangia, was discarded. The tube containing the supernatant was gently inverted 2 or more times to ensure mixing. Three separate aliquots of the suspension were then removed and counted on a haemocytometer. The concentration of zoospores was then diluted to $4.0 \times 10^{5}$ zoospores $\mathrm{ml}^{-1}$ in TGHL broth. We added $200 \mu \mathrm{l}$ of this suspension to each well of a 96 -well plate and the first 5 columns of a second 96 -well plate. A visual inspection of the wells using an inverted micro- scope confirmed that all wells contained similar numbers of active zoospores. The 96 -well plates were then placed in a $20^{\circ} \mathrm{C}$ incubator.

After $3 \mathrm{~d}$, microscopic examination confirmed that there was considerable growth in each well, with mature zoosporangia and active zoospores. We removed the broth from each well and replaced it with $200 \mu \mathrm{l}$ of 1 of $3 \mathrm{NaOCl}$ concentrations; 1, 6 and $12 \%$, or a control (TGHL). Each $\mathrm{NaOCl}$ dilution at each exposure period had 7 replicates and the control group had 10 replicates.

In order to prevent Batrachochytrium dendrobatidis in the control group from continuing reproduction, controls were processed immediately after addition of the TGHL. The $200 \mu \mathrm{l}$ of TGHL was removed and $200 \mu \mathrm{l}$ of a dilute saline (DS) solution added (Boyle et al. 2003). The bottom and sides of each control well were scraped 16 times, and the corner where the sides meet the bottom of the well was scraped 4 times with a sterile wooden dowel. The $200 \mu \mathrm{l}$ aliquot of DS was then removed and placed in a $1.5 \mathrm{ml}$ Micro tube (Sarstedt). A second $200 \mu$ aliquot of DS was then added to the well and the process was repeated. All samples were immediately centrifuged at $16100 \mathrm{~g}$ for $3 \mathrm{~min}$ to form a pellet of $B$. dendrobatidis. Most of the supernatant $(280 \mu \mathrm{l})$ was removed and discarded and the tube placed in a $-60^{\circ} \mathrm{C}$ freezer.

Following 1, 6, 15 and $24 \mathrm{~h}$ of exposure of Batrachochytrium dendrobatidis to $\mathrm{NaOCl}$, the procedure detailed above for the control group was repeated with the $3 \mathrm{NaOCl}$ dilution treatments. As with the TGHL in the controls, the $\mathrm{NaOCl}$ solution was removed and discarded from each well prior to the addition of DS. Before the addition and removal of the $\mathrm{NaOCl}$ solution, a visual inspection of each well was conducted to assess fungal condition. Quantitative real-time TaqMan ${ }^{\circledR}$ (Applied Biosystems) PCR assays were run on all samples using a Rotor-Gene ${ }^{\mathrm{TM}} 6000$ (Corbett Life Sciences) as described by Boyle et al. (2004) with some modifications. In order to test for possible inhibition by residual $\mathrm{NaOCl}$, a repeat triplicate analysis was performed on 4 samples containing the highest concentration of $\mathrm{NaOCl}(12 \%)$, thus the most likely to inhibit, and 4 controls containing no $\mathrm{NaOCl}$ by incorporating the TaqMan ${ }^{\circledR}$ Exogenous internal positive control (IPC) (0.6x Exo IPC Mix, 0.6x Exo IPC DNA) into the assay. Inhibition is indicated by threshold cycle $(\mathrm{Ct})$ values significantly higher than those obtained for the negative control.

Examination of the data made it clear that some results did not require statistical hypothesis testing. When results were not certain by examination, hypotheses were tested using 1-way ANOVA to compare differences among exposure periods within $\mathrm{NaOCl}$ treatments, and Bonferroni-adjusted $t$-tests 
were used to determine whether groups of $\mathrm{NaOCl}$ treatments that did not differ significantly among themselves differed significantly from controls. All statistical analyses were performed using STATISTICA 7.1 (StatSoft).

\section{RESULTS}

The $1 \% \mathrm{NaOCl}$ solution did not differ significantly in effectiveness across the 4 exposure periods (ANOVA, $F=0.777$, df $=3,27, p=0.519$ ), and comparison with the control treatment indicated that it did not denature Batrachochytrium dendrobatidis DNA effectively enough over any of the 4 exposure periods for use as a denaturing agent $(t=-0.340$, df $=$ $36, p=0.736$, Fig. 1). Only very low numbers of zoospores were detected in the $6 \% \mathrm{NaOCl}$ treatment (Fig. 1). These did not differ among exposure period treatments (ANOVA, $F=0.531$, df $=3,27 \mathrm{p}=0.665$ ) and were significantly reduced compared to controls $(t=3.088, \mathrm{df}=36, \mathrm{p}=0.004)$. The $12 \% \mathrm{NaOCl}$ treatment was $100 \%$ effective and denatured all B. dendrobatidis DNA across all exposure periods (Fig. 1). No inhibition from the $12 \% \mathrm{NaOCl}$ was detected with the internal positive controls (mean $\mathrm{Ct}$ value $12 \%$ $\mathrm{NaOCl}=28.12$, mean $\mathrm{Ct}$ value control $=28.61, t=$ -0.985 , df $=6, p=0.363$ ). Visual inspection of each well prior to the removal of $\mathrm{NaOCl}$ revealed that zoosporangia and zoospores from the 6 and $12 \%$

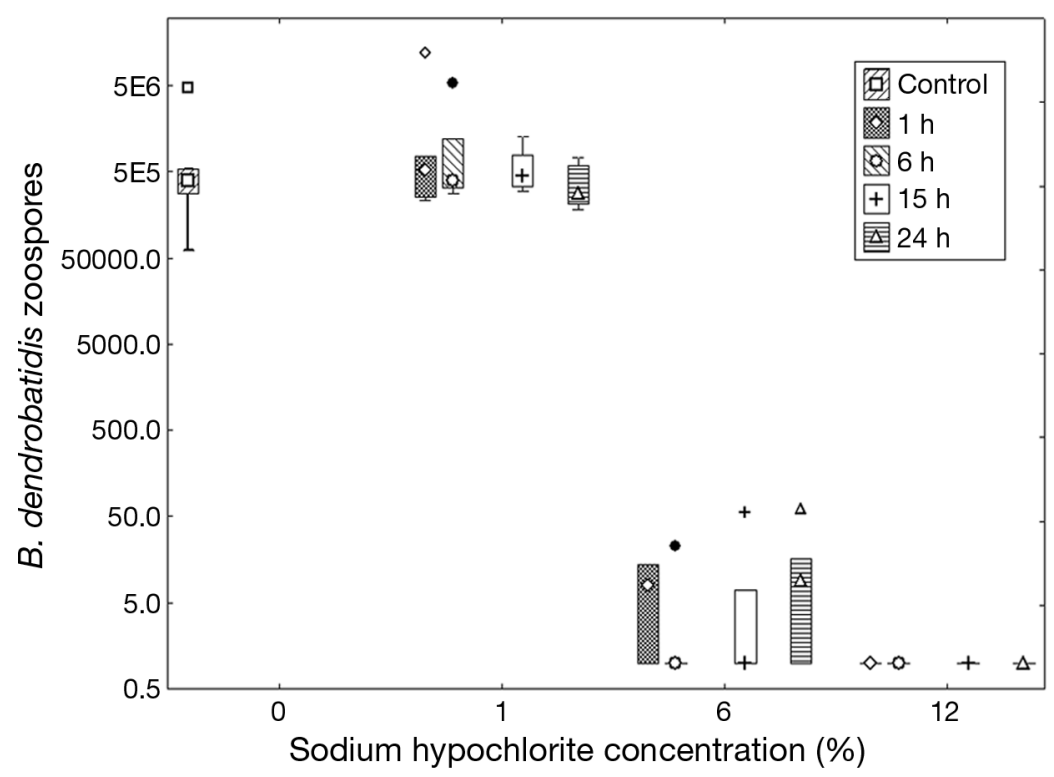

Fig. 1. Batrachochytrium dendrobatidis. Number of zoospores detected in controls and at 3 concentrations of sodium hypochlorite $(\mathrm{NaOCl})$ after varying periods of exposure. Symbols within boxes represent the median; boxes represent the upper and lower quartiles; whiskers represent the non-outlier spread; symbols above boxes represent the outliers
$\mathrm{NaOCl}$ treatments were severely fragmented and completely unrecognisable. The $1 \% \mathrm{NaOCl}$ treatment wells contained shrivelled and shrunken but recognizable zoospores and zoosporangia.

\section{DISCUSSION}

The present study found that $12 \% \mathrm{NaOCl}$ can be effectively used to denature $100 \%$ of even very high densities of Batrachochytrium dendrobatidis within 1 h. Similarly, 6\% NaOCl was extremely effective, with a mean of only 6 to 13 zoospore equivalents detected across all exposure periods (Fig. 1). This represents a mean reduction from the controls of $99.999 \%$. As the PCR assay can detect as little as 1 zoospore (Boyle et al. 2004), a minimum of ca. 100000 contaminant zoospores on average would need to be present for a false positive result following treatment with $6 \% \mathrm{NaOCl}$. In practice, the number of $B$. dendrobatidis zoospores contaminating equipment is likely to be a fraction of the levels examined in the present study. For example, the highest level of B. dendrobatidis reported on a swab sample from an infected amphibian is 545000 zoospores on a Mixophyes fasciolatus (Hyatt et al. 2007). Any contamination of equipment is likely to be at levels far below those of severely infected amphibians. It is possible then that a $6 \% \mathrm{NaOCl}$ solution can be used to denature DNA sufficiently on clean equipment to prevent false positives through PCR. However, as field equipment often contains soil, plant material and other particulates which may either shield $B$. dendrobatidis or decrease the efficiency of $\mathrm{NaOCl}$ (LeChevallier et al. 1988), it is far safer and advisable to use $12 \% \mathrm{NaOCl}$ to prevent cross-contamination. Prior to soaking in $\mathrm{NaOCl}$, equipment should be cleaned to reduce the negative impact of any attached particles. The $1 \% \mathrm{NaOCl}$ solution did not effectively denature $B$. dendrobatidis zoospores at any of the exposure periods and should not be used to prevent sample contamination.

Most household bleach products contain between 4.00 and $6.15 \% \mathrm{NaOCl}$, and the most common concentration of commercially available bulk $\mathrm{NaOCl}$ is $12 \%$, making the concentrations tested here readily available to most researchers. Exactly how $\mathrm{NaOCl}$ deactivates microorganisms has never been experimentally shown (Gomes et al. 2001). However, it is believed that cell 
death is a result of oxidation of sulfhydryl groups and amino acids on the exterior of the cell by $\mathrm{OCl}^{-}$ (Eventov et al. 1998). NaOCl destroys DNA in a similar manner through oxidative damage (Ohnishi et al. 2002, Kemp \& Smith 2005), resulting in the breakdown of DNA into segments shorter than that recognized by the PCR assay (Prince \& Andrus 1992).

Because PCR is now the preferred diagnostic test for chytridiomycosis (Hyatt et al. 2007), it is crucial to minimise contamination so that results are comparable and reliable. Just as great care should be taken in the laboratory during processing of samples to prevent contamination, equal care must be taken in the field during the collection of samples. When sampling amphibians for infection, each individual should be captured with a separate pair of gloves or plastic bag. If individuals are captured in a bag, a fresh pair of gloves should be worn during each swabbing and each swab should be housed individually. These precautions should be sufficient to prevent cross-contamination of DNA during field surveys where the amphibians are captured by hand and returned to their natural habitat following swabbing. However, as researchers move from documenting occurrence and prevalence of chytridiomycosis into more manipulative experimental work, the risk of contaminating samples through shared contact presents an important problem. For example, reusing experimental equipment such as containers, enclosures, sorting trays and nets in conjunction with PCR can result in contamination of samples. Also, equipment used to search for Batrachochytrium dendrobatidis in the environment, such as filter holders and tubing, could cross-contaminate samples (Kirshtein et al. 2007). As $\mathrm{NaOCl}$ is toxic, great care should be taken to avoid release or spillage of bleach into water bodies, drains or drainages when in the field. Used bleach that needs to be disposed of should always be carried back to the lab or, if absolutely necessary, spread onto a flat surface such as a paved road to evaporate. $\mathrm{NaOCl}$ evaporates quickly and breaks down to water, oxygen and table salt $(\mathrm{NaCl})$. However, other chemicals may be added during production, particularly in household cleaning products (Clarkson \& Moule 1998).

Bleach already forms a part of many researchers' tool kit for the purposes of disinfection. Our experiment shows that $\mathrm{NaOCl}$ can also be used to denature Batrachochytrium dendrobatidis DNA to prevent its recognition by PCR and reduce the likelihood of cross-contamination of samples.

Acknowledgements. The present study was funded by the Department of Environment and Heritage (Australia) tender 42/2004 and 43/2004. We thank R. Campbell, who ran the diagnostic PCR tests and S. Garland, who ran the internal positive control tests.

\section{LITERATURE CITED}

Annis SL, Dastoor FP, Ziel H, Daszak P, Longcore JE (2004) A DNA-based assay identifies Batrachochytrium dendrobatidis in amphibians. J Wildl Dis 40:420-428

Berger L, Speare R, Daszak P, Green DE and others (1998) Chytridiomycosis causes amphibian mortality associated with population declines in the rain forests of Australia and Central America. Proc Natl Acad Sci USA 95: 9031-9036

> Boyle DG, Hyatt AD, Daszak P, Berger L and others (2003) Cryo-archiving of Batrachochytrium dendrobatidis and other chytridiomycetes. Dis Aquat Org 56:59-64

Boyle DG, Boyle DB, Olsen V, Morgan JAT, Hyatt AD (2004) Rapid quantitative detection of chytridiomycosis (Batrachochytrium dendrobatidis) in amphibian samples using real-time TaqMan PCR assay. Dis Aquat Org 60:141-148

Clarkson RM, Moule AJ (1998) Sodium hypochlorite and its use as an endodontic irrigant. Aust Dent J 43:250-256

> Eventov VL, Andrianova MY, Kukaeva EA (1998) Detoxification and disinfection with sodium hypochlorite. Biomed Eng (NY) 32:349-352

> Gomes BPFA, Ferraz CCR, Vianna ME, Berber VB, Teixeira FB, Souza-Filho FJ (2001) In vitro antimicrobial activity of several concentrations of sodium hypochlorite and chlorhexidine gluconate in the elimination of Enterococcus faecalis. Int Endod J 34:424-428

Hyatt AD, Boyle DG, Olsen V, Boyle DB and others (2007) Diagnostic assays and sampling protocols for the detection of Batrachochytrium dendrobatidis. Dis Aquat Org 73: 175-192

> Johnson ML, Berger L, Phillips L, Speare R (2003) Fungicidal effects of chemical disinfectants, UV light, desiccation and heat on the amphibian chytrid Batrachochytrium dendrobatidis. Dis Aquat Org 57:255-260

> Kemp BM, Smith DG (2005) Use of bleach to eliminate contaminating DNA from the surface of bones and teeth. Forensic Sci Int 154:53-61

- Kirshtein JD, Anderson CW, Wood JS, Longcore JE, Voytek MA (2007) Quantitative PCR detection of Batrachochytrium dendrobatidis DNA from sediments and water. Dis Aquat Org 77:11-15

> LeChevallier MW, Cawthon CD, Lee RG (1988) Factors promoting survival of bacteria in chlorinated water supplies. Appl Environ Microbiol 54:649-654

Lips KR, Brem F, Brenes R, Reeve JD and others (2006) Emerging infectious disease and the loss of biodiversity in a Neotropical amphibian community. Proc Natl Acad Sci USA 103:3165-3170

- Martyny J, Harbeck R, Pacheco K, Barker E and others (2005) Aerosolized sodium hypochlorite inhibits viability and allergenicity of mold on building materials. J Allergy Clin Immunol 116:630-635

> Matsui E, Kagey-Sobotka A, Chichester K, Eggleston PA (2003) Allergic potency of recombinant Fel d 1 is reduced by low concentrations of chlorine bleach. J Allergy Clin Immunol 111:396-401

Ohnishi S, Murata M, Kawanishi S (2002) DNA damage induced by hypochlorite and hypobromite with reference to inflammation-associated carcinogenesis. Cancer Lett 178:37-42

> Pessier AP, Nichols DK, Longcore JE, Fuller MS (1999) Cutaneous chytridiomycosis in poison dart frogs (Dendrobates spp.) and White's tree frogs (Litoria caerulea). J Vet Diagn Invest 11:194-199

Prince AM, Andrus L (1992) PCR: how to kill unwanted DNA. Biotechniques 12:37-42 
Rachowicz LJ, Knapp RA, Morgan JAT, Stice MJ, Vredenburg VT, Parker JM, Briggs CJ (2006) Emerging infectious disease as a proximate cause of amphibian mass mortality. Ecology 87:1671-1683

Sehulster LM, Hollinger FB, Dreesman GR, Melnick JL (1981) Immunological and biophysical alteration of hepatitis B virus antigens by sodium hypochlorite disinfection. Appl Environ Microbiol 42:762-767

Skerratt LF, Berger L, Speare R, Cashins S and others (2007) Spread of chytridiomycosis has caused the rapid global decline and extinction of frogs. EcoHealth 4:125-134

Editorial responsibility: Alex Hyatt,

Geelong, Victoria, Australia
Speare R, Berger L, Skerratt LF, Alford R and others (2004) Hygiene protocol for handling amphibians in field studies. Available at: www.jcu.edu.au/school/phtm/PHTM/frogs/ field-hygiene.pdf

Webb R, Mendez D, Berger L, Speare R (2007) Additional disinfectants effective against the amphibian chytrid fungus Batrachochytrium dendrobatidis. Dis Aquat Org 74:13-16

Woodhams DC, Vredenburg VT, Simon MA, Billheimer D and others (2007) Symbiotic bacteria contribute to innate immune defenses of the threatened mountain yellowlegged frog, Rana muscosa. Biol Conserv 138:390-398

Submitted: October 9, 2007; Accepted: March 17, 2008 Proofs received from author(s): May 21, 2008 